\title{
Evaluating the Catastrophic Rainfall of 14 July 2016 in the Catchment Basin of the Urbanized Strzyza Stream in Gdańsk, Poland
}

\author{
Wojciech Szpakowski*, Michał Szydłowski \\ Gdańsk University of Technology, Faculty of Civil and Environmental Engineering, \\ Department of Hydraulic Engineering, 11 Narutowicza str. 80-233 Gdańsk, Poland
}

Received: 29 May 2017

Accepted: 18 July 2017

\begin{abstract}
We analyzed the causes, the course, and consequences of the extreme precipitation events that occurred 14 July 2016 in the watershed of Strzyza Creek in Gdańsk, Poland. Automated rain gauges located in Strzyża catchment registered a total precipitation lasting about 16 hours - from 129 to $160 \mathrm{~mm}$ of rain depth. More in-depth analysis based on rain data collected by Gdańsk University of Technology (GUT) rain station was done. The course of rainfall was compared with existing rain models on the national range and also with local rain formula. The results showed that, according to the Chomicz classification, the rainfall can be qualified as torrential. Its course far exceeded the theoretical values calculated for the probability of occurrence 1\% (return time: 100 years). Although the analyzed rain episode was characterized by extremely high instantaneous rainfall intensities, the duration of the most intensive middle stage of about eight hours caused the highest daily rain sum registered in Gdańsk in the history of meteorological measurements. As a result, the rainfall caused two fatalities in the lower part of the Strzyza watershed. It was noted that this type of rain qualified as an extraordinary event at the turn of the XX and XXI centuries in areas located in the Mediterranean region. Rainfalls that currently occurr in this part of Europe are also characterized by proportionally higher parameters that should be considered as an indisputable effect of climate change on a global scale.
\end{abstract}

Keywords: urban flooding, extreme events, rainfall, DDF curve, IDF curve

\section{Introduction}

Extraordinary rainfall events occur in areas adjacent to sea shores all over the world. Referring to the European

*e-mail: wszp@pg.gda.pl

continent, the following events may be mentioned: 13-14 January 1994 in Crete (123 mm rainfall in five hours, daily sum of precipitation about $183 \mathrm{~mm}$ ) [1] and 9 September 2010 on the Amalfi Coast, Italy (135 mm within six hours and maximum intensity of $90 \mathrm{~mm}$ per hour) [2].

The catastrophic event that occurred 14 July 2016 in Gdańsk is characterized by rain parameters similar to 
the above-mentioned rainfalls in southern Europe. The average monthly sum of precipitation in the Gdańsk area is the highest for the month of July and reaches about $75 \mathrm{~mm}$ [3]. However, for the second time in the Gdańsk region in the 21 st century, the health and safety of residents were threatened as a result of the unforeseen rainfall. The first extraordinary rain episode occurred the 9 July 2001, when daily precipitation in the Strzyza catchment exceeded 120 $\mathrm{mm}$. The second such rainfall took place on 14 July 2016 with a daily sum of precipitation exceeding $150 \mathrm{~mm}$. The rainfall area in both cases was similar and contained the whole watershed of Strzyza creek and neighboring stream catchments in the Gdańsk agglomeration. The sum of total precipitation in 2016 was 20 percent higher than in 2001, but losses resulting from the rainfall were much smaller in 2016. Expenses incurred by the city authorities for flood protection in Gdańsk in the amount of $€ 80$ million protected the residents living in the southern districts of Gdańsk - especially in the neighborhood of Radunia Canal. Only in Strzyza catchment were flood losses in 2001 and 2016 similar to each other. The greatest loss was the death of two people trying to save their goods in the basement of one building situated within the flooded area of Strzyża catchment in 2016.

\section{Material and Methods}

\section{Meteorological Causes of 14 July 2016 Rain Fall}

From 10 July southeastern Poland was under the influence of tropical air masses associated with a center of high-pressure over the Balkans. Two thermal zones developed over Poland: the northwestern part of the country remained under the influence of maritime polar air mass with temperatures oscillating around $25^{\circ} \mathrm{C}$. The maximum temperature on 11 July amounted to almost $28^{\circ} \mathrm{C}$ in Lębork and Szczecin and $26^{\circ} \mathrm{C}$ in Koszalin [4]. In the rest of the country the maximum air temperature significantly exceeded $30^{\circ} \mathrm{C}$. On 11 July $34^{\circ} \mathrm{C}$ was recorded in Opole, Legnica, Kalisz, and Płock [4]. On 13 July the tropical air mass moved away to the southeast of the country while central Poland experienced local rainfalls associated with the colder air mass transition. The short-duration rainfall with a sum of $30-40 \mathrm{~mm}$ caused extensive flooding of urban infrastructure in Warsaw. The measured sum of daily precipitation in Torun was almost $75 \mathrm{~mm}$. The rainfall area along the eastern border on 12 and 13 July 2016 was stretched with daily values greater than $30 \mathrm{~mm}$ in the region of Białystok, about $50 \mathrm{~mm}$ in the region of Włodawa, and almost $70 \mathrm{~mm}$ in the Bieszczady Mountains [5].

On 14 and the 15 July 2016 a shallow low-pressure area moved from southeastern to northern Poland. A wide system of atmospheric fronts was arising. The eastern part of the country was in a hot and humid tropical air mass while the rest of the country remained in a warm mass of polar air. Over the Gulf of Gdańsk, the extremely warm air from the east, initially linked with the warm atmospheric front that was transformed in an occluded front, flowed in. Precipitation lasted continuously for 14 to 17 hours (approximately from 10:30 UTC on 14 July until 03:00 on 15 July 2016) in the area of Gdańsk. From the Gulf of Gdańsk to the western part of Poland - along the line Gdańsk-Poznan-Legnica - a continuous rain zone was formed. The registered daily sum of rain did not exceed $110 \mathrm{~mm}$. The only exception was Gdańsk agglomeration, when the orographic processes caused much stronger rain. The daily sum of precipitation in forests of Tri-cities Landscape Park in Gdańsk-Oliwa reached $170 \mathrm{~mm}$ [6]. The above recorded value exceeded twice the monthly precipitation average for July.

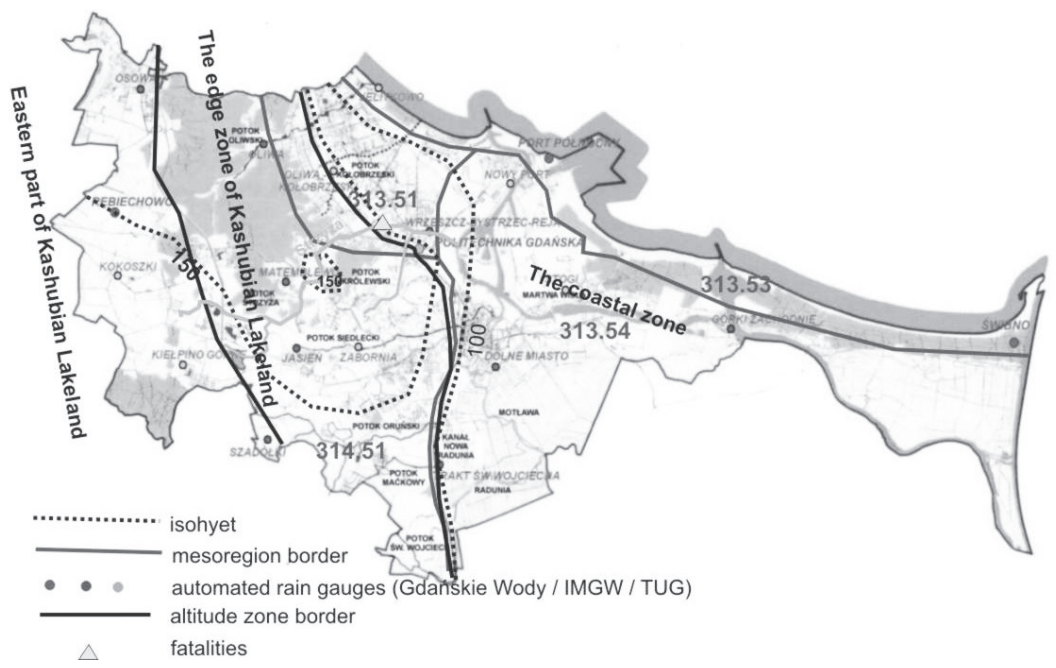

Fig. 1. Mesoregions in Gdańsk area according to Kondracki [7], and division of Gdańsk on different height zones as suggested by the network of automated rain measurement gauges [6]. 


\section{July 2016 Rainfall Distribution in the Gdańsk Region}

The Gdańsk region includes areas both adjacent to the shoreline of the Gulf of Gdańsk and the region of moraine hills of the Kaszuby Lakeland region. The entire rainfall episode in the Gdańsk agglomeration occurred during daily rainfall on 14 July 2016 (from 06:00 UTC 14 July to 06:00 15 July) and was registered by the Gdańsk rain monitoring system (12 automated rain gauges controlled, calibrated, and verified by the Gdańskie Wody Company [6]), meteorological stations of the Institute of Meteorology and Water Management, and Gdańsk University of Technology automatic rain gauge and Hellmann ombrometer. As mentioned, the warm and moist air mass flowing from the Gulf of Gdańsk to the west rose up at the same time over the moraine hills of Kaszuby. The difference in altitude between the shoreline and the highest part of western Gdańsk exceeds $160 \mathrm{~m}$. As a result of adiabatic vertical lifting of air mass in the region on the edge zone of Kaszuby, rapid condensation of water vapor occurred. Consequently additional orographic precipitation processes appeared. Hence, the most intense rainfall occurred in the area between the lower terrace Tri-City and Kaszuby. Therefore, in Gdańsk three basic height zones can be distinguished due to different weather processes. Different and significant sums of rain were recorded within each zone. (Fig. 1):

- The coastal zone includes the lowest part of Gdańsk, situated adjacent to the Gulf of Gdańsk and characterized by a very gentle altitude gradient. According to the Kondracki division [7], the above zone includes mesoregions Vistula Spit (313.53), Vistula Delta Plain (313.54), and the lowest and easternmost part of the mesoregion Kaszuby Coast (313.51). Total daily rainfall in close proximity to the Gulf of Gdańsk does not exceed $100 \mathrm{~mm}$.

- The edge zone of Kaszuby Lakeland is an area of steep gradient in terrain altitude, from about 10 to $150 \mathrm{~m}$ a.s.l. The edge zone includes the western part of the mesoregion Kaszuby Coast (313.51) with a total daily rainfall of about $150 \mathrm{~mm}$ and the eastern part of the Kaszuby Lakeland mesoregion (314.51), where total daily precipitation exceeded $150 \mathrm{~mm}$ and reached $170.2 \mathrm{~mm}$ in the Oliwa rain gauge [6]. Exceptional precipitation was registered in the area of Ogrodowa Street, wherein total rain depth on 14 June 2016 was only $130 \mathrm{~mm}$. It should be noted, however, that this station is located in the lowest local area of Strzyża Valley surrounded by moraine hills.

- The eastern part of Kaszuby Lakeland is an area characterized by a gentle gradient of altitude compared with its edge zone. It is assumed that this area is located on the western side of National Highway S6. In the southern part of the analyzed area the total daily rainfall exceeded $100 \mathrm{~mm}$, while in the northern part, Gdańsk Osowa, the amount of precipitation was about $160 \mathrm{~mm}$. At the stations of the University of Gdańsk located in Kaszuby (approximately 20-30 km west
Table 1. Highest values of daily rain sums in Poland measured in the 20th and 21st centuries (until 2010), together with values measured on 14 July 2016 at Oliwa Station [6, 9-10].

\begin{tabular}{|c|c|c|}
\hline Location, voivodeship & $\begin{array}{l}\text { Daily rain } \\
\text { sum }(\mathrm{mm})\end{array}$ & Date \\
\hline $\begin{array}{c}\text { Hala Gąsienicowa, } \\
\text { małopolskie }\end{array}$ & 300.0 & 30.06 .1973 \\
\hline Witów, małopolskie & 285.0 & 16.07 .1934 \\
\hline Leskowiec & 242.9 & 18.07.1970 \\
\hline Stańcowa & 234.4 & 18.07.1970 \\
\hline Magurka, ślaskie & 229.3 & 18.07.1970 \\
\hline Szczyrk, ślaskie & 224.0 & 18.07.1970 \\
\hline Nieszawa & 221.7 & 8.07 .1955 \\
\hline Sienno k. Kielc & 218.5 & 19.05.1941 \\
\hline Wałbrzych, dolnośląskie & 206.5 & 18.06.1979 \\
\hline Jakuszyce, dolnośląskie & 204.3 & 07.08 .2006 \\
\hline Maków Podhalański, & 190.8 & 25.07.2001 \\
\hline Zakopane, & 172.3 & 16.07 .1934 \\
\hline Gdańsk Oliwa, & 170.2 & 14.07 .2016 \\
\hline $\begin{array}{l}\text { Kasprowy Wierch, } \\
\text { małopolskie }\end{array}$ & 166.1 & 08.07.1997 \\
\hline Bielsko-Biała, śląskie & 162.7 & 16.05 .2010 \\
\hline Kielce, & 155.2 & 24.07 .2001 \\
\hline Mławka k. Mławy & 155.1 & 14.06 .1999 \\
\hline Bielsko Biała, Śląskie & 147.4 & 21.08 .1972 \\
\hline Łeba, Pomorskie & 141.0 & 24.07 .1988 \\
\hline Pielgrzymów, opolskie & 135.7 & 15.08 .2008 \\
\hline Cieklin, podkarpackie & 132.5 & 21.06 .1955 \\
\hline Słubice, Lubuskie & 132.5 & 08.08 .1978 \\
\hline $\begin{array}{c}\text { Ustrzyki Dolne, } \\
\text { podkarpackie }\end{array}$ & 132.0 & 12.06 .1957 \\
\hline Baligród Mchawa & 130.6 & 26.07 .2005 \\
\hline Mosty, lubelskie & 129.3 & 11.08 .2006 \\
\hline Tarnów, Małopolskie & 128.7 & 16.07 .1934 \\
\hline $\begin{array}{c}\text { Gdańsk Rębiechowo, } \\
\text { Pomorskie } \\
\end{array}$ & 127.7 & 09.07.2001 \\
\hline Zielonki (Stare Babice) & 126.5 & 05.08 .2002 \\
\hline Ulszkowice, pomorskie & 125.6 & 09.07 .2001 \\
\hline Radostowo, pomorskie & 122.2 & 09.07 .2001 \\
\hline Słubice, lubuskie & 121.5 & 04.07.2009 \\
\hline
\end{tabular}

of Gdańsk), the daily sum of rain on 13-15 July 2016 did not exceed $50 \mathrm{~mm}$ [8]. Similarly, meteorological stations located on the eastern side of the Vistula River recorded 25-40 mm daily rain, which was not exceptional. 


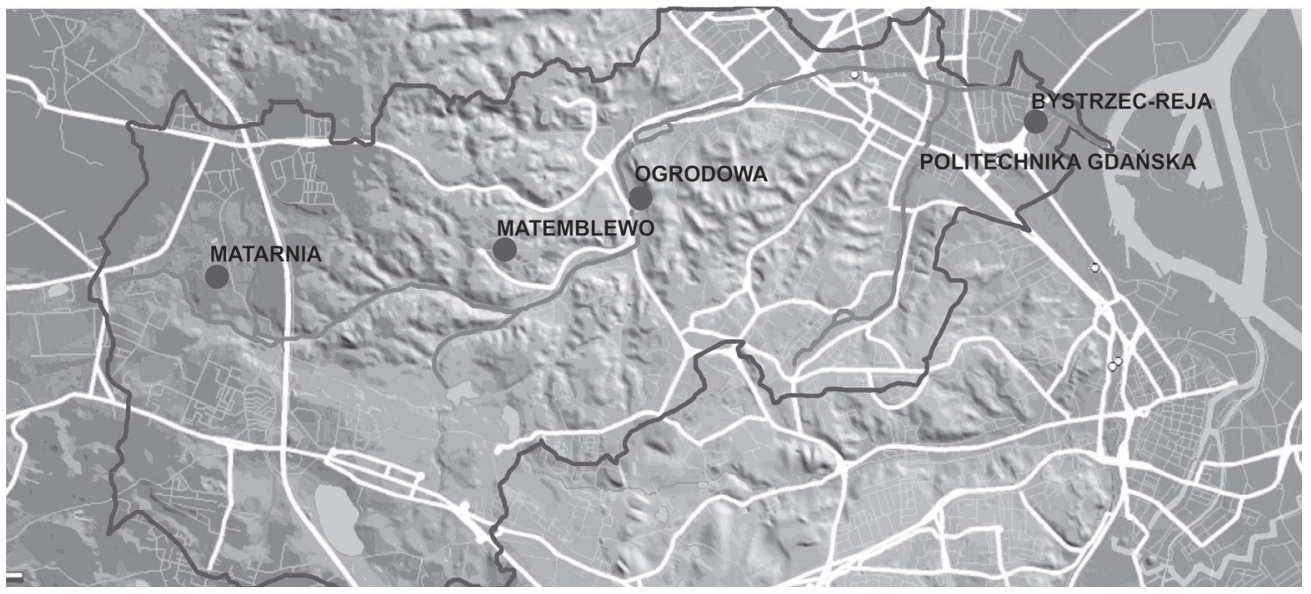

Fig. 2. Digital terrain model (DTM) of the Strzyża Stream catchment area with catchment boundary and precipitation gauges: Politechnika Gdańska - Gdańsk University of Technology - GUT (light point), Gdańskie Wody (circle) [12].

In view of the presented daily sum of precipitation distribution on 14 July 2016, the variability of altitude shows that an additional $60-70 \mathrm{~mm}$ of rain in the region of the edge zone of Kaszuby has the origin in the orographic processes provoked by moving air masses.

Compared to precipitation events in Europe, the analyzed rainfall was not a unique episode. When hills or mountains in the neighborhood of the coastline are higher than hills surrounding the Gdańsk agglomeration, the orographic effect of rainfall may be much more intense. On 3 October 2015 in France, a pressure system provoked the inflow of hot and humid air mass into the Côte d'Azur area. Air rising up to $1,000 \mathrm{~m}$ caused dramatic rainfall $20 \mathrm{~km}$ from the coast of the Mediterranean sea onto land. $106 \mathrm{~mm}$ of rain was noted in Cannes within one hour and $175 \mathrm{~mm}$ in two hours. The total sum of precipitation was $196 \mathrm{~mm}$. The rainfall was accompanied by strong lightning due to storm clouds that developed in the upper troposphere. Twenty people were killed in the flooding and the calculated initial losses exceeded $€ 500$ million [9].

The rain episode of 14 July 2016 in Gdańsk is one of the most intensive daily precipitation events recorded in Poland [10-11] (Table 1). Higher daily rain sums have been registered mainly in the mountains, where normal precipitation is twice higher compared to Gdańsk.

As mentioned, the greatest losses due to the rain which covered the region on 14 July occurred in Strzyza Creek Watershed. Therefore, the rainfall event and its effects in the largest catchment of Gdańsk stream have been analyzed in more detail.

\section{Characteristics of Strzyza Catchment}

At $13.2 \mathrm{~km}$ long, the Strzyza flows from the source region at a height of about $140 \mathrm{~m}$ a.s.l. Its catchment area includes wooded upland moraine, industrial zones, and sites of dense urban development. Longitudinal declines in the stream are in the range $0.5-5 \%$, and the mean catchment slope in the eastern direction is approximately
$1 \%$. The total area of Strzyza catchment is equal to $33.9 \mathrm{~km}^{2}$ (Fig. 2). Nine reservoirs with a total area of 13.46 hectares and the retention capacity of approximately $215,000 \mathrm{~m}^{3}$ operate in the catchment. The biggest of them are Kielpinek and Jasien, located in the upper part of the watershed with total retention capacity of $108,000 \mathrm{~m}^{3}$, and Srebrniki Reservoir with a water storage capacity of $64,500 \mathrm{~m}^{3}$, located on the border of the edge zone of Kaszuby and the lower terrace of the city [6].

Normal rainfall in Strzyza catchment varies from 550 (lower part) to 700 (upper part) $\mathrm{mm}$. The annual sum of precipitation in subsequent years differs significantly, depending on location details. For example, for 2009 the rain height variation between stations was $82 \mathrm{~mm}$, and for 2010 up to $171 \mathrm{~mm}$. This indicates a significant spatial variation of rainfall in this part of Gdańsk [12].

In the closing cross-section of Strzyza Basin, the average annual flow rate SSQ in the period 2000-14 amounted to $0.175 \mathrm{~m}^{3} / \mathrm{s}$. The highest average annual flow rate of the mentioned interval WSQ occurred in 2001 and amounted to $0.222 \mathrm{~m}^{3} / \mathrm{s}$. On the contrary, the smallest average annual flow rate NSQ occurred a year earlier at $0.137 \mathrm{~m}^{3} / \mathrm{s}$. Maximum flow rate corresponding the bankfull stage is about $22 \mathrm{~m}^{3} / \mathrm{s}$ [13].

Total precipitation on 14 July 2016 in Strzyza Catchment ranged from $129.9 \mathrm{~mm}$ at Ogrodowa station to $162.1 \mathrm{~mm}$ at Matemblewo station. The results of precipitation were recorded on an automatic tippingbucket rain gauge Davis Vantage Pro 2 at the weather station located at Gdańsk University of Technology (GUT) and were taken into account for detailed analysis. An automatic station was installed in 2008 in the weather garden of the Faculty of Civil and Environmental Engineering of GUT, and records of meteorological parameters with a time step of 10 minutes and measurement accuracy of $0.2 \mathrm{~mm}$ were realized. In the daily rain 14 July the rain gauge registered $150.8 \mathrm{~mm}$ of rain. The control rain gauge (Hellmann instrument) indicated $152.2 \mathrm{~mm}$ at the same time. 


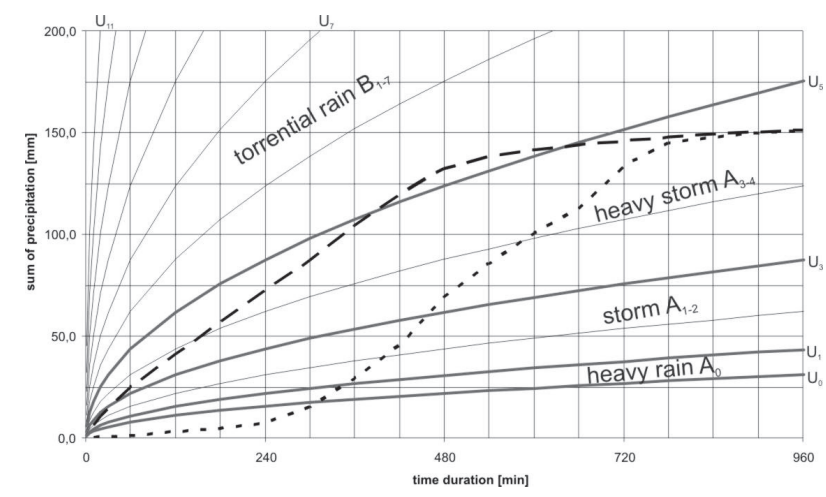

Fig. 3. Sum rain curve of the 14 July 2016 rainfall event (dotted line) and maximum precipitation totals at predetermined time curve (dashed line) against Chomicz scale curves $\mathrm{U}_{0-11}[13]$.

\section{Characteristics of Used Rain Models}

The basic classification of storm selection for a single rainfall episode is adopted based on the Chomicz rainfall intensity scale, which is popular in Poland [14].

$$
U_{k}=\alpha_{k} \sqrt{t} \text {. where } \alpha_{k}=\sqrt{2^{k}}
$$

...where $U_{k}$ is the upper limit value of rainfall depth for $k$ th grade of Chomicz scale $(\mathrm{mm})$ and $t$ is the time of rain duration (min). The boundary between storms and torrential rains is grade $k=5$ on that scale. Area $A_{0}$ means heavy rains, $A_{1-2}$ storms, $A_{3-4}$ heavy storms, and $B$ torrential rains (Fig. 3).

In the analyses of randomly occurring single rainfalls, nationwide rain models (Reinhold, Lambor and Bogdanowicz-Stachy) [15] and a local rain model (Weinerowska-Bords) [3] were used. The obtained results were compared with Rozanski analysis based on the rainfall data of Polish meteorological stations until 1929, which was prepared in 1930 [16]. The Reinhold equation is based on the knowledge of precipitation intensity for the time duration of 15 minutes and return period of $C=1$ year (which corresponds to the probability occurrence $p=100 \%$ ), which is designated as $q_{15}$. Rain intensity $q$ in function of $q_{15}$ and also time duration $t$ and return period for rainfall $C$ is described by Eq. 2 [17]:

$$
q=q_{15} \frac{38}{t+9}(\sqrt[4]{C}-0,369)\left[\mathrm{dm}^{3} /(\mathrm{s} \mathrm{ha})\right]
$$

The values of annual rainfall intensity $q_{15}$, initially established in 1940 for the historic territory of Germany, is for Gdańsk $93 \mathrm{dm}^{3}$ (s ha). In Germany these values are determined currently individually for each catchment and gathered in the KOSTRA atlas as guidelines for environmental design purposes in Germany [15].

Lambor proposed a rain intensity formula with the probability of occurrence $p$ and duration time $t$ in function of normal annual rain [18]:

$$
J=\frac{(38-12 \cdot \log p) H^{0,28}}{(t+c)^{n}}+d
$$

The parameters in the above equation $-c, d, n-$ are defined for the Gdańsk region as follows:

$$
\begin{gathered}
c=\frac{1}{1000}\left(20.92 \cdot H \cdot p^{0,345}-0,15 \cdot p-2.0\right) \\
d=\frac{1}{1000}(47.3-0.023 p) \\
n=0.779-0.164 \cdot H
\end{gathered}
$$

...where $J$ is precipitation intensity $(\mathrm{mm} / \mathrm{h}), H$ is the value of normal rain (mean annual value) for selected localization (m). The Lambor formula was widely used in the 1950s, but now this model is less often used [17].

The rain model proposed by Bogdanowicz and Stachy, commonly called the IMGW formula, was published at the end of the last century. It was established on the basis of maximum annual precipitation data registered by 20 meteorological station in 1960-90. According to the authors, the formula can be used for establishing the probability of exceedance of rainfall episodes $p \in(0 ; 1]$ [15]. The maximal precipitation depth $P(\mathrm{~mm})$ with the probability of exceedance $p(-)$ depending on the duration time $t(\mathrm{~min})$ is as follows [19]:

$$
P_{\max , p}=1,42 \cdot t^{1 / 3}+\alpha \cdot(-\ln p)^{0,584}
$$

Parameter $\alpha$, which consists of the location and the scale for the northwestern part of Poland, is defined as:

$$
\alpha=3,92 \cdot \ln \left(t_{m}+1\right)-1,662
$$

for the duration time $5 \leq \mathrm{t} \leq 30 \mathrm{~min}$

$$
\alpha=9,16 \cdot \ln \left(t_{m}+1\right)-19,6
$$

for the duration time $30 \leq t \leq 60 \mathrm{~min}$

$$
\alpha=2,223 \cdot \ln \left(t_{m}+1\right)+10,639
$$

for the duration time $120 \leq \mathrm{t} \leq 720 \mathrm{~min}$

$$
\alpha=9,472 \cdot \ln \left(t_{m}+1\right)-37,032
$$

for the duration time $720<\mathrm{t} \leq 4320 \mathrm{~min}$

Local rain models are based on local precipitation data. It is worth mentioning the results obtained for Kraków [20-21] and Wrocław [22-23]. For the Gdańsk region Weinerowska-Bords established the local rain formula based on 122 rain episodes collected by the GUT meteorological station in the period 1991-2010 [3]. All rain episodes that passed the criterion $2 / 3 \mathrm{U}_{0}$ on the Chomicz scale were selected as a source data to be used in global optimization with computational procedure 
CRS (controlled random research). The formula for precipitation intensity $q\left[\mathrm{dm}^{3} /(\mathrm{s}\right.$ ha) $]$ for the duration time $t<60$ minutes is written as:

$$
q=-a \cdot \ln p+b
$$

$$
\begin{gathered}
a=0.011306 \cdot t^{2}-1.500482 \cdot t+69.2635(6 \mathrm{a}) \\
b=0.075719 \cdot t^{2}-9.04707 \cdot t+374.845(6 \mathrm{~b})
\end{gathered}
$$

$\ldots$ and for the duration time $t \geq 60 \mathrm{~min}$.:

$$
q=a \cdot p^{-b}
$$

$$
a=0.017767 \cdot t^{2}-2.756281 \cdot t+247.28426
$$

$$
b=0.002902 \cdot t+0.271315
$$

Because of the duration time of analyzed rain episodes and their lasting period not exceeding 120 minutes, the practical use of equations 6 and 7 is limited by the probability of exceedance greater than $p=5 \%$ and the rain duration time $\mathrm{t} \leq 120 \mathrm{~min}$.

Using data concerning the torrential rains that occurred in Polish lands until 1929, Rozanski proposed a formula based on the Hellman equation, which represents the upper limit of total precipitation, depending on the rain duration time. The use of the formula is limited to the rain duration of 360 minutes. With regional coefficients for northern Poland (Pomerania) it can be written as follows [16]:

$$
\begin{aligned}
I & =a+\frac{b}{\sqrt[3]{t}} \\
a & =-0,512 \\
b & =+5,640
\end{aligned}
$$

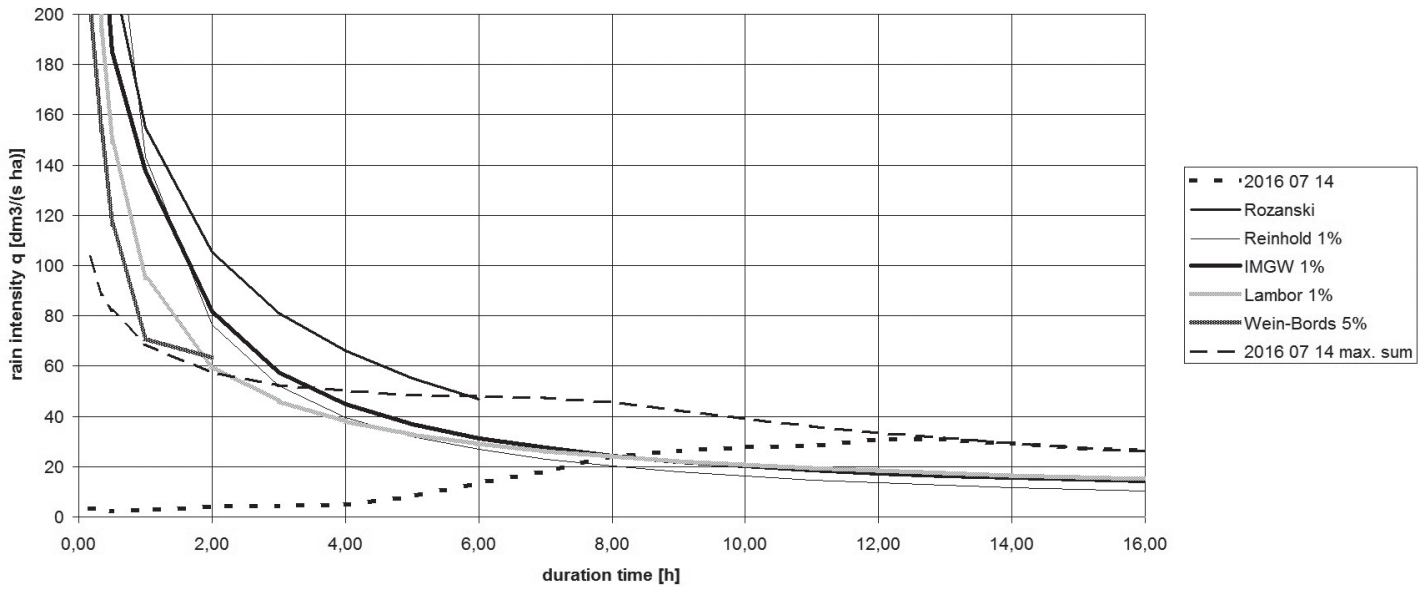

Fig. 4. Maximum rain intensity at predetermined time curve (2016 0714 max. sum) and rain intensity curve from the beginning of the 14 July 2016 (2016 07 14) event together with IDF curves of rain models.
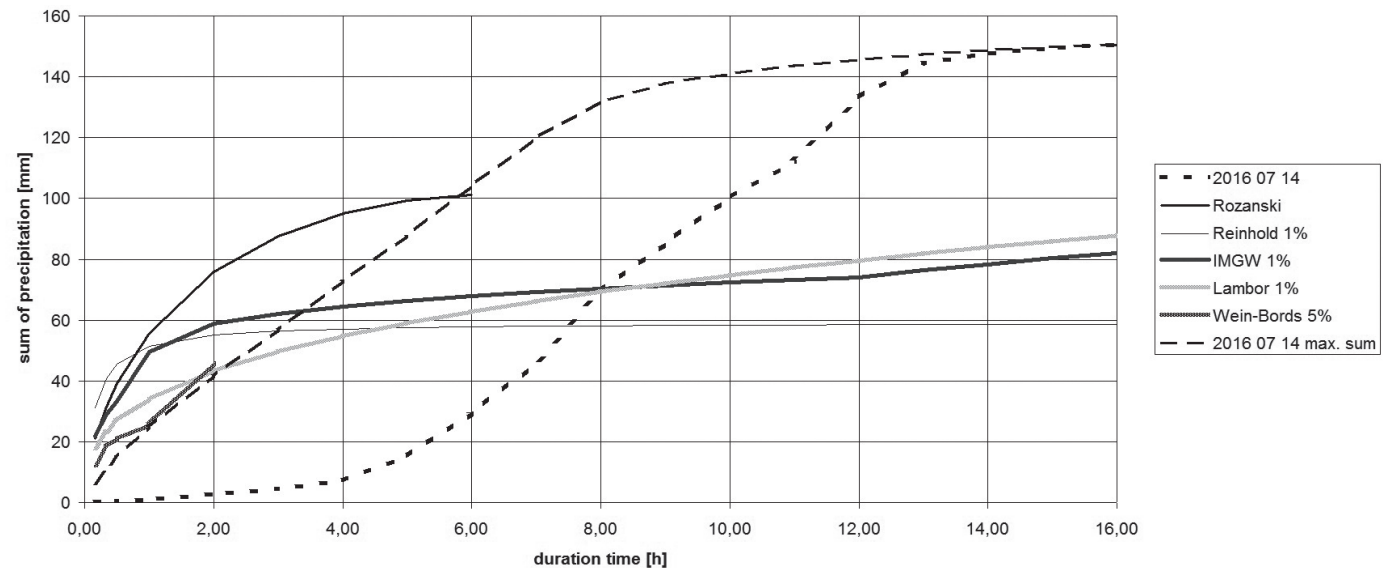

Fig. 5. Maximum rain sum at predetermined time curve (2016 0714 max. sum) and rain sum curve from the beginning of the 14 of July 2016 (2016 07 14) together with DDF curves of rain models. 


\section{Results and Discussion}

The duration of the14 July 2016 rain at the GUT station was approximately 16 hours. According to the Chomicz scale, three stages of temporal distribution can be distinguished:

1. 260 minutes, from about $10: 40$ to about 15:00 UTC. This stage is characterized by low intensity of precipitation, below the curve $\mathrm{U}_{1}$, which indicates a normal rain. The sum of precipitation at this stage was $8.4 \mathrm{~mm}$.

2. 480 minutes, from about 15:00 to about 23:00 UTC, characterized by high intensity of precipitation. After 390 minutes above curve $\mathrm{U}_{5}$, which indicates torrential rain. The sum of precipitation at this stage was 130.4 $\mathrm{mm}$, and mean rainfall intensity was greater than 0.27 $\mathrm{mm} / \mathrm{min}$.

3. 220 minutes, from about 23:00 UTC to the end of the rain. This stage is characterized by low intensity of precipitation, below curve $U_{1}$, which indicates a normal rain. The sum of precipitation at this stage was $12.0 \mathrm{~mm}$.

Taking into account the course of the rain sum curve (Fig. 3), the analyzed rain did not exceed the $U_{5}$ curve of the Chomicz scale and can be categorized as a heavy storm. However, due to the course of the middle stage expressed as the curve of maximum totals of precipitation at a predetermined time, the rainfall is undoubtedly classified as a torrential rain. It should be noted that the Chomicz criterion is considered a preliminary indicative criterion and has a mainly descriptive significance [15].

Different rain durations (from 10 minutes to 16 hours) were assumed in analysis. For the predetermined time the duration was the highest total sum of precipitation (curves 20160714 max. sum in Figs 4-5) from the entire event. The values calculated from the rainfall histogram were also represented in Figs 4-5 (curves 201607 14).

Taking into account equations 2-8 for different rain models, intensity-duration-frequency (IDF) and depthduration-frequency (DDF) curves were elaborated upon. IDF curve (Fig. 4) presents the calculated rain intensity $q\left[\mathrm{dm}^{3} /(\mathrm{s} \mathrm{ha})\right]$ in function of its frequency of coincidental occurrence and rain duration $t(\mathrm{~min})$. The value of rain intensity for the rain duration time from 5 minutes to 16 hours were calculated. The probability of rain occurrence of $p=1 \%$ for the Reinhold (Eq. 2) Lambor (Eq. 3) and IMGW (Eq. 5) rain models was supposed in the calculations. For the local rain model (Eqs. 6 and 7) a value of $p=5 \%$ was assumed due to the limitation of the model. The upper limit of total precipitation proposed by Rozanski (Eq. 8) and curves representing the real event of 14 of July 2016 (2014 0714 and 20140714 max.sum) are also presented in Fig. 4.

On the basis of rainfall intensity $q$, expressed in $\mathrm{dm}^{3} /$ ( $\mathrm{s}$ ha), the intensity of precipitation can be determined in $\mathrm{mm} / \mathrm{min}$ or $\mathrm{mm} / \mathrm{h}$ using the transformation:

$$
1 \frac{d m^{3}}{s \cdot h a}=\frac{60}{10000} \frac{m m}{\min }=\frac{3600}{10000} \frac{\mathrm{mm}}{h}
$$

After multiplying by time the intensity of rainfall in $\mathrm{mm} / \mathrm{min}$ or $\mathrm{mm} / \mathrm{h}$, a total sum of precipitation in a determined time can be found. The dependence of total precipitation sum in function of rain time duration and the probability of rainfall occurrence is described by the DDF curve, which is shown in Fig. 5 for the same curves as in Fig. 4.

Calculations show that the course of rainfall recorded on 14 July 2016 at the Gdańsk University of Technology rain station exceeded the probability of the rain occurrence of $1 \%$ calculated for all rain models after eight hours of rain. During this time $76 \mathrm{~mm}$ of rain were collected, which is quite close to the $70 \mathrm{~mm}$ collected during the 3.5 hours of the middle stage of rain. Taking into account the maximum total sum of precipitation for a predetermined time, already in the interval of 3.5 hours all theoretical values of rainfall intensity for 100 years return time were exceeded. The maximal sum of rain for the predetermined time of 360 minutes was below the upper limit of total precipitation proposed by Rozanski [16], who collected rain data in the first three decades of the $20^{\text {th }}$ century.

Due to the fact that the middle stage with the highest rain intensity lasted up to eight hours, the total sum of precipitation over $130 \mathrm{~mm}$ nearly doubled the theoretical values of IMGW and Lambor rain models for the probability of occurrence of $1 \%$. The intensity of precipitation in this phase varied from 12 to $22 \mathrm{~mm} /$ hour. Therefore, the duration time of the middle stage with an average intensity of more than $16 \mathrm{~mm} /$ hour (45 $\mathrm{dm}^{3} /(\mathrm{s} \mathrm{ha})$ ) was the major anomaly with respect to the course of historical rainfall episodes. Additionally, the sum of the rain, which was registered at Gdańsk University of Technology within 16 hours of rainfall, exceeds by $30 \%$ the rain characterized by the return time of 500 years as calculated by Twardosz for Kraków conditions [20].

To estimate the effects of catastrophic precipitation in the Strzyza Catchment, the commonly known SCS method was used [24-25]. In order to evaluate the curve number of SCS method (CN) for the entire catchment, the whole basin was divided into 43 sub-areas with estimated constant value of the $\mathrm{CN}$ parameter for each sub-area. This parameter depends on the surface development, soil conditions, and land slopes. The mean $\mathrm{CN}$ coefficient for the mean moisture level was established as 78.64 [26], which corresponds to $\mathrm{CN}=61$ for the dry humidity level and was adopted for the effective rainfall estimation. Finally, for the 14 July 2016 episode the effective precipitation and in consequence the Strzyza outflow was estimated at $63.8 \mathrm{~mm}$, which constitutes $42.3 \%$ of total precipitation (Table 2).

The results show that in the middle stage of the rain (from the 7 th to the $13^{\text {th }}$ hours of rain) the outflow volume at the mouth of Strzyza Stream is far beyond the estimated channel capacity corresponding to the shoreline water level as $22 \mathrm{~m}^{3} / \mathrm{s}$ [13].

The recommendations of the German Association for Water, Wastewater, and Waste Management DWA-A118: 2006 [27] indicate that in order to determine the rain 
Table 2. Estimating the effective rain in successive rain hours based on Gdańsk University of Technology automated rain gauge data regarding 14 July 2016 using the SCS method [24].

\begin{tabular}{|c|c|c|c|}
\hline Time & Rain & \multicolumn{2}{|c|}{ Effective rain } \\
\hline hour & $\mathrm{mm}$ & $\mathrm{mm}$ & $\mathrm{m}^{3} / \mathrm{s}$ \\
\hline 1 & 1 & 0.0 & 0.0 \\
\hline 2 & 2 & 0.0 & 0.0 \\
\hline 3 & 1.6 & 0.0 & 0.0 \\
\hline 4 & 2.8 & 0.0 & 0.0 \\
\hline 5 & 7.8 & 0.1 & 0.5 \\
\hline 6 & 14 & 1.6 & 14.7 \\
\hline 7 & 16.6 & 4.2 & 39.1 \\
\hline 8 & 23.6 & 9.1 & 86.1 \\
\hline 9 & 15.8 & 7.7 & 72.9 \\
\hline 10 & 15.2 & 8.4 & 79.2 \\
\hline 11 & 12 & 7.2 & 67.7 \\
\hline 12 & 21 & 13.6 & 127.7 \\
\hline 13 & 11.2 & 7.7 & 72.2 \\
\hline 14 & 3.2 & 2.2 & 21.1 \\
\hline 15 & 1.8 & 1.3 & 11.9 \\
\hline 16 & 1.2 & 0.8 & 8.0 \\
\hline Total: & 150.8 & 63.8 & \\
\hline
\end{tabular}

probability occurrence of $10 \%$, there should be at least 30 years of rain courses data of both short and long episodes. Taking these guidelines into account, some authors have suggested that in urban conditions the intensity duration frequency curve can be calculated only for a return time of 20 years $(p=5 \%)$ in the present state of knowledge [28].

\section{Conclusions}

The rainfall on 14 July 2016 in Gdańsk was exceptional. The analysis of the data was based on a comparison with existing rain models for a $1 \%$ probability of occurrence corresponding to a return time of 100 years. Analyses showed that the rain course and its parameters do not correspond to the Polish models of precipitation as described by the IDF and DDF curves. The main reason is the course of the middle rainfall stage, with an average intensity of $45 \mathrm{dm}^{3} /(\mathrm{s} \mathrm{ha})$ and having a long duration time of about eight hours. This catastrophic rainfall was classified as torrential characterized by number $\mathrm{B}_{1}$ of the Chomicz scale.

During eight hours of the most intense rainfall, about $130 \mathrm{~mm}$ of rain fell into the Strzyża Catchment. Assuming the maximal safety water outflow of $22 \mathrm{~m}^{3} / \mathrm{s}$ in Strzyza Estuary, the excess of water created for at least seven hours an additional ground retention in subterranean areas (e.g., cellars, underground garages, underground commercial buildings) or outflowed from Strzyza Watershed in a different way (in disagreement with sanitary sewage system laws).

The rainfall event that took place in Gdańsk Strzyza Basin on 14 July 2016 was catastrophic. The total sum of precipitation for the 16-hour rainfall episode in Gdańsk University of Technology $(150.8 \mathrm{~mm})$ was one of the highest daily precipitation rates ever recorded in northern Poland. However, there was no extreme rain intensity in its course, but due to the duration of the rain, the total amount of precipitation was that high. It is important to note that the health and safety hazards of inhabitants due to torrential rains can occur more frequently because of the change in the causes of such events (e.g., climate change). This confirms only a 15 -year interval of "calm" between rainfall catastrophes in Strzyza Catchment between 2001 and 2016.

Extreme rainy episodes observed both in Poland and Europe should convince the authorities to renew guidelines for a safer dimensioning of stormwater management systems.

\section{References}

1. KOUTROULIS A.G., TSANIS I.K., A method for estimating flash flood peak discharge in a poorly gauged basin: Case study for the 13-14 January 1994 flood, Giofiros basin, Crete, Grece, Journal of Hydrology 385 (150-164) 2010.

2. VIOLANTE C., BRACA G., ESPOSITO E., TRANFAGLIA G., The 9 September 2010 torrential rain and flash flood in the Dragone catchment, Atrani, Amalfi Coast (southern Italy), Nat. Hazards Earth Syst. Sci., 16, 333, 2016, doi:10.5194/nhess-16-333-2016.

3. WEINEROWSKA- BORDS K., Development of Local IDF-formula Using Controlled Random Search Method for Global Optimization, Acta Geophysica 63,1, 2015 DOI: 10.2478/s11600-014-0242-5.

4. Weekly Hydrological Newsletter July 5-12 2016 IMGW PIB, Warszawa (accessed on: 18 July 2016).

5. Weekly Hydrological Newsletter July 12-19 2016 IMGW PIB, Warszawa (accessed on: 25 July 2016).

6. Gdańskie Wody sp. z o.o., (The Water of Gdańsk) Available at: www.Gdańskiewody.pl (accessed on: 10 December 2016).

7. KONDRACKI J., Regional geography of Poland, PWN, Warszawa, 2002 [In Polish].

8. Gdańsk University Meteorological Newsletter BorucinoKościerzyna-Ostrzyce, 76, 125 Lipiec ISSN 2081-884X, Gdańsk 2016 [In Polish].

9. KERAUNOS French observatory storms and tornadoes (An extraordinary storm on the Cote d'Azur on October 3, 2015), at. Keraunos.org 2016 [In French].

10. IMGW - PIB (Institute of Meteorology and Water Management - National Research Institute) Climate record in Poland, atmospheric precipitation, at www.imgw.pl (accessed on: 10 December 2016).

11. Vademecum Dangerous meteorological phenomena, genesis, effects, return time, part one - spring, summer, IMGW - PIB Institute of Meteorology and Water 
Management - National Research Institute Warszawa 2013 [In Polish].

12. WEINEROWSKA-BORDS K., SZYDŁOWSKI M, BIELECKA K., Analysis of temporal and spatial variability of precipitation in the Strzyza catchment in Gdańsk, Inżynieria Morska i Geotechnika, 6, 2012 [In Polish].

13. SZYDŁOWSKI M., MIKOS-STUDNICKA P., The influence of quality of hydrological data on the outflow estimation from the urban watershed on the example of the Strzyża stream in Gdańsk., Inżynieria Ekologiczna Vol. 44, 139, 2015 [In Polish].

14. CHOMICZ K., Heavy rain and storms in Poland. News of the Hydrological and Meteorological Service, 2, 4, Warszawa 1951 [In Polish].

15. KOTOWSKI A., KAŹMIERCZAK B., DANCEWICZ A., Precipitation modelling for stormwater design, PAN Warszawa 2010 [In Polish].

16. RYBCZYŃSKI M., POMIANOWSKI K., WÓYCICKI K., Hydrology, part 1 precipitation-outflow Wyd. Warsaw University of Technology 1933 [In Polish].

17. WEINEROWSKA-BORDS K., Wpływ uproszczeń na obliczanie spływu deszczowego w zlewni zurbanizowanej, Wyd. PG, Gdańsk 2010 [In Polish].

18. DĘBSKI K., Mainland Hydrology Part II Physics of water, atmospheric precipitation and evaporation, Wyd. Komunikacyjne, Warszawa 1959 [In Polish].

19. BOGDANOWICZ E., STACHỲ J. Maximum rainfall in Poland. Design characteristics. Research Materials, s: Hydrology and Oceanology, 23. IMGW, Warszawa 1998 [In Polish].

20. TWARDOSZ, R. Probabilistic model of maximum precipitation depths for Kraków (southern Poland, 18862002) Theor Appl Climatol 98 (37) 2009. doi:10.1007/ s00704-008-0087-4

21. WAŁĘA A., KACZOR G., STEPIEWSKI B., The role of local precipitation models in designing rainwater drainage systems in urban areas: a case study in Krakow, Poland, Pol. J. Environ. Stud. 25, 5 2016, 2139, DOI: 10.15244/ pjoes/62961

22. KAZIMIERCZAK B., KOTOWSKI A., Depth-durationfrequency rainfall model for dimensioning and modelling of Wroclaw drainage system, Environmental Protection Engineering, 38 (4) 2012 DOI: 10.5277/EPE120411.

23. KOTOWSKI A., KAZIMIERCZAK B., Probabilistic models of maximum precipitation for designing sewerage, Journal of Hydrometeorology, 14, 2013, DOI: http://dx.doi. org/10.1175/JHM-D-13-01.1.

24. U.S. Department of Agriculture and Soil Conservation Service, A Method for Estimating Volume and Rate of Runoff in Small Watersheds, Washington, DC: Tech. Paper 1973.

25. KOLERSKI, T., KOWALIK, M. Runoff calculations from uncontrolled catchments of Radunia Channel during the 2001 rain flood, Maritime Engineering and Geotechnics 1, 2014 [In Polish].

26. SZYDŁOWSKI M., MIKOS-STUDNICKA P., ZIMA P., WEINEROWSKA-BORDS K., HAKIEL J., SZAWURSKA D. Stormwater and snowmelt runoff storage control and flash flood hazard forecasting in the urbanized coastal basin, in: $14^{\text {th }}$ International Symposium Water Management and Hydraulic Engineering 2015, Institute of Water Structures, FCE, Brno University of Technology, 2015.

27. Recommendations of the German Association for Water, Wastewater and Waste Management (Deutsche Vereinigung fur Wasserwirtschaft, Abwasser und Abfall) - DWAA118:2006 Hydraulische Bemessung und Nachweis von Entwasserungssystemen 2006 [In German].

28. SULIGOWSKI Z., Torrential rains, stormwater design, Magazyn Instalatora 12, 2016 [In Polish]. 